\title{
MECHANISM OF BEACH EROSION AT THE WEST OF PHU QUOC ISLAND, SOUTHERN VIETNAM
}

\author{
HUYNH TRUNG TIN ${ }^{1}$, LE HOAI NAM ${ }^{2}$, BUI TRONG VINH ${ }^{1}$ \\ Email: httinvn@gmail.com \\ ${ }^{1}$ Faculty of Geology \& Petroleum Engineering - HCMUT \\ ${ }^{2}$ Southern Branch of Center for Environment Consultancy and Technology - VEPA
}

Received: June 15, 2013

\section{Introduction}

Phu Quoc Island locates in Gulf of Thailand, Southern Vietnam. Several years ago, due to the effect of climate change and the development of beach tourism, beach erosion in the Western beach occurred seriously. Beach erosion has both damaged the coastal resident's houses and affected to the socioeconomic in the area. Therefore, it is necessary to study about the cause to beach erosion, which can propose the mitigation method, ensure the stable development for the island. Study area is framed from Cua Can to Duong To beach, see Fig. 1 [7].

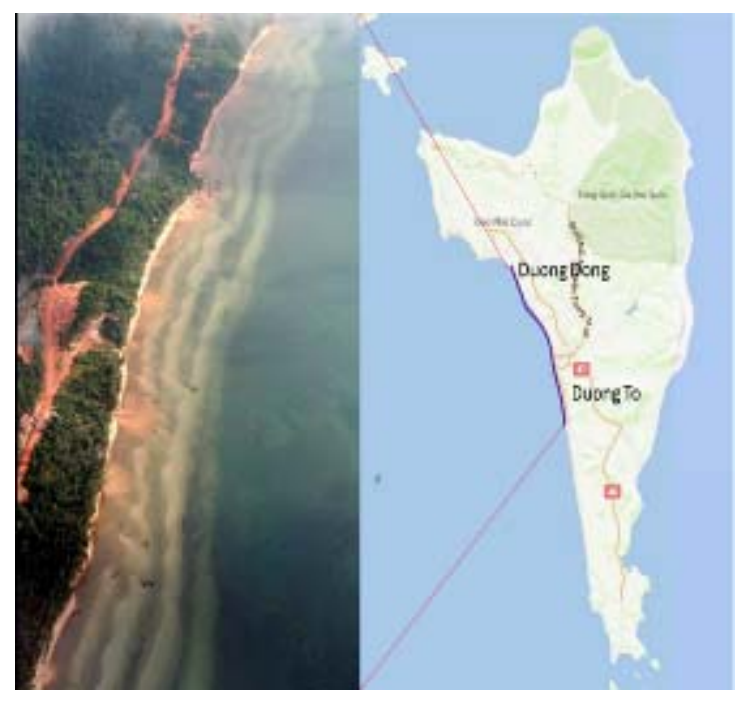

Figure 1. Study area

\section{Natural condition}

\subsection{Natural condition}

Tidal observation:

Phu Quoc Island is affected by regular diurnal regime of the Gulf of Thailand with the difference between two tidal crests is around $1 \mathrm{~m}$. Highest water level is $+1.55 \mathrm{~m}$ and the lowest is around $+0.5 \mathrm{~m}$.

\section{Wind:}

Western beach faces to the Gulf of Thailand, is called the "gateway" of the monsoon. The Southwest monsoon season is dominant. In history, maximum wind velocity gets $31 \mathrm{~m} / \mathrm{s}$ [1]. Fig. 2 characterises the predominant winds at the Phu Quoc island in June and November 2010 [1].

\section{Wave field:}

In the southwest monsoon season, wave height is higher than those in the Northeast monsoon season. Maximum wave height in the summer measured is $2 \mathrm{~m}$. Average wave height is around $0.6-1 \mathrm{~m}$. In the winter (NE monsoon season), maximum wave height measured is about $1.0 \mathrm{~m}$. Average wave height appears is $0.5 \mathrm{~m}$. Fig. 3 presents the average wave height and mean water level at Phu Quoc station from 1979 to 2010 [1].

\section{Beach state:}

Western beach with many straight and steep beaches are interrupted by exposed bed rock capes. Littoral material compounds of discrete sediment 
$\left(\mathrm{D}_{50}=0,3 \mathrm{~mm}\right)$. Erodible materials are easily damaged by surge wave. Table 1 shows the state of

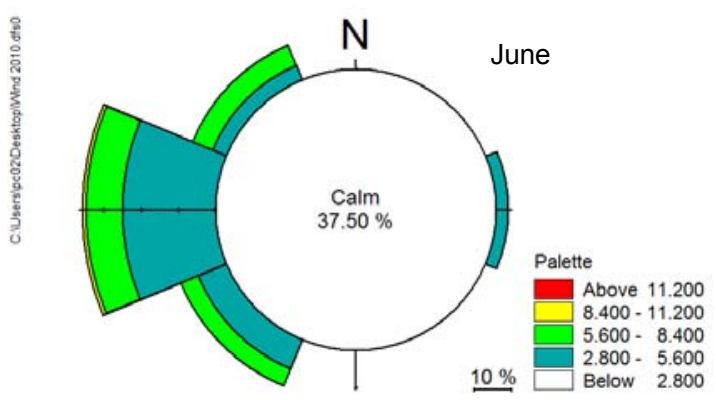

western beach in relation of wave characteristic and beach material.

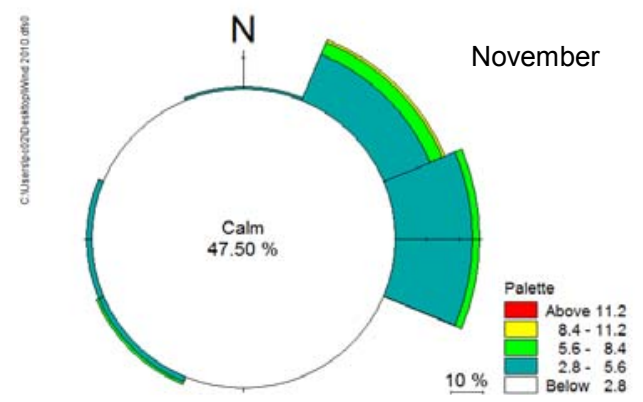

Figure 2. Predominant winds at Phu Quoc island

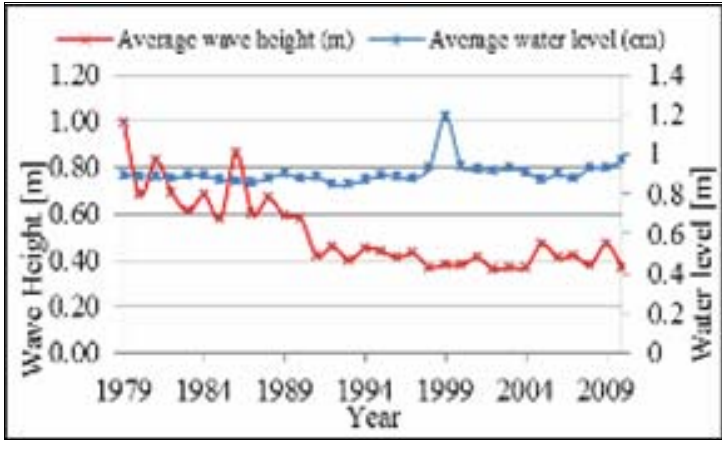

Figure 3. Annual wave height and mean water level at Phu Quoc station from 1979 to 2010

Table 1. Beach state at Western beach - Phu Quoc Island

\begin{tabular}{|c|c|c|c|}
\hline$D_{50}$ & $W_{s}$ & $\Omega=$ & $N_{S} / T$ \\
\hline \multirow{2}{*}{$\mathrm{mm}$} & \multirow{2}{*}{$\begin{array}{c}W_{s}= \\
14^{*}\left(D_{50}\right)^{1,1}\end{array}$} & $\begin{array}{c}\mathrm{N}-\mathrm{E} \text { monsoon } \\
(\mathrm{Nov})\end{array}$ & $\begin{array}{c}\text { S-W monsoon } \\
\text { (May) }\end{array}$ \\
\hline & & $\begin{aligned} & \mathrm{H}_{\mathrm{b}}= 0.7 \mathrm{~m}, \mathrm{~T}= \\
& 3.3 \mathrm{~s}\end{aligned}$ & $\begin{array}{c}\mathrm{H}_{\mathrm{b}}=0.3 \mathrm{~m}, \mathrm{~T}= \\
5 \mathrm{~s}\end{array}$ \\
\hline 0.3 & 3.723586 & 0.0244 & 0.016 \\
\hline
\end{tabular}

Where: $H_{b}$ is wave breaker height $(m), W_{s}$ is the sediment fall velocity based on Stoke's law (Gibbs et all. 1971) $(\mathrm{m} / \mathrm{s})$ and $\mathrm{T}$ is the wave period (s). According to Wright and Short (1984) [3], shoreline is divided to 3 types: wave power reflex $(\Omega<1)$, intermediation $(1<\Omega<6)$ and dispersal wave power. Western beach is in range of $\Omega<1$, it means the wave does not break in line but rather crash on and surge up the steep beach face [5].

\section{Beach erosion state}

To assess the state of beach erosion, field trips had been carried out. The slope of beach calculated is about 1:400. The gentle beach compounded by weak consolidated material is easily damaged by surge wave.

On the other hand, at the Duong Dong beach, the beach is steeper (Fig. 4, 5). The slope of beach calculated is around 1:118. The steep beach is one of the main causes to beach erosion in this area.
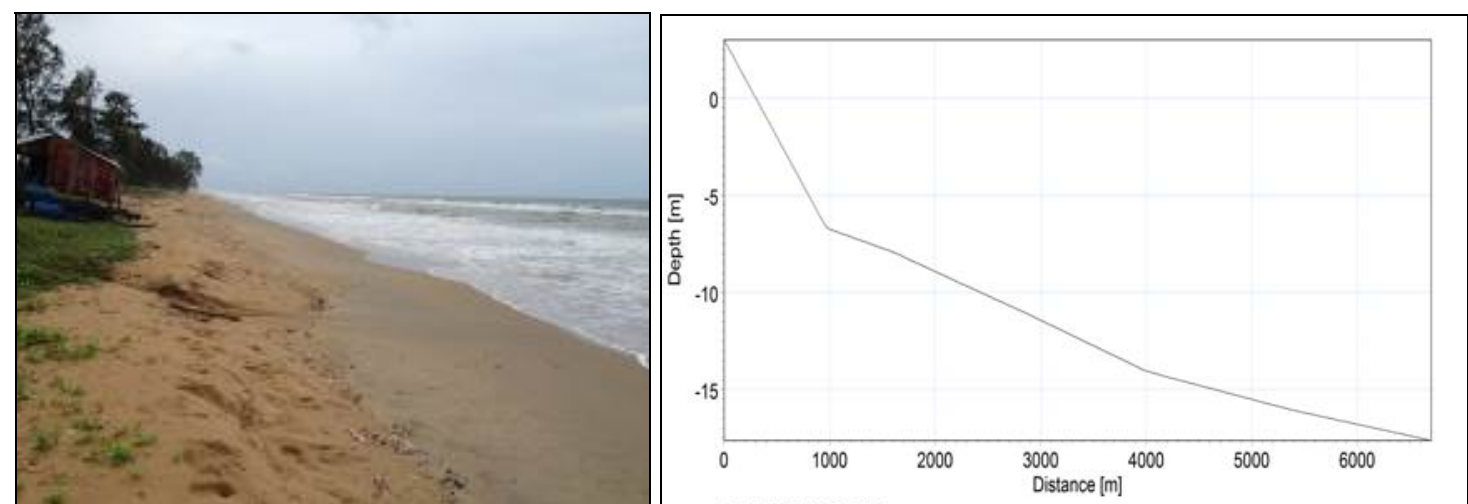

Figure 4. Beach erosion and typical section at Duong To beach 

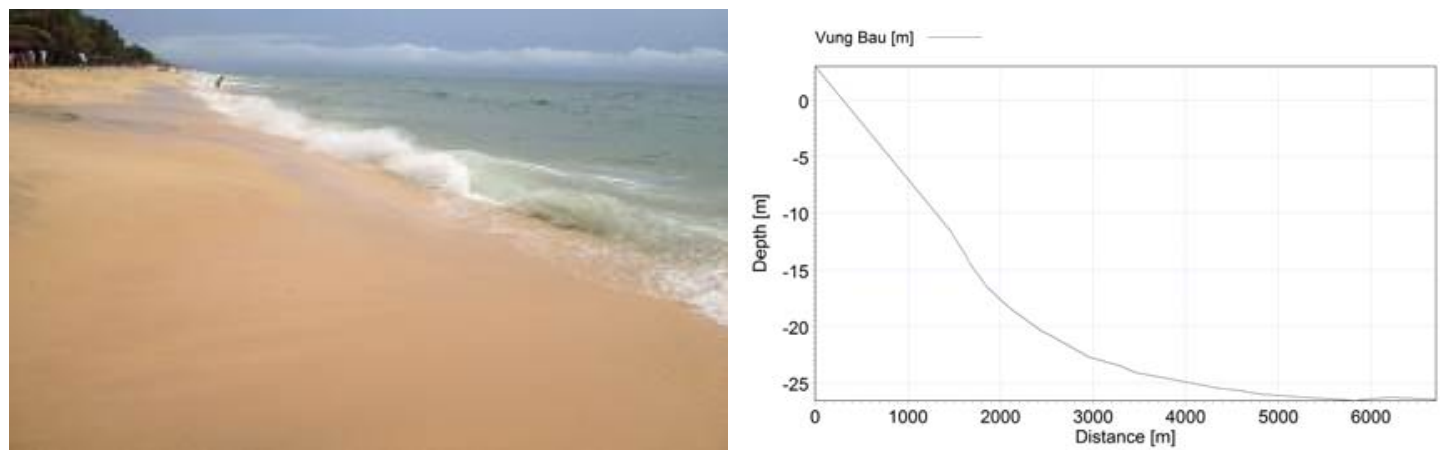

Figure 5. A beach section at western beach at Vung Bau beach

\section{Numerical modeling}

To model the coastal process at Western beach, numerical model has been established [6]. In combination of hydrodynamic, sand transport and spectral wave model, the impact of natural factors to erosion mechanism has been proved. Data input for numerical model is presented in Table 2.

Table 2. Numerical model data input

\begin{tabular}{|c|c|c|c|}
\hline No. & Parameter & Time & Source \\
\hline 1 & Bed level & 2006 & Etopo 2 by NOAA ${ }^{1}$ \\
\hline 2 & Water level & 2012 & Global data by $\mathrm{DHI}$ \\
\hline 3 & Sediment & 2011 & Field investigation \\
\hline 4 & Wave & 2010 & Wave-watch $\mathrm{III}^{2}$ \\
\hline 5 & Coastline & 2010 & Landsat $7^{3}$ \\
\hline 6 & $\begin{array}{l}\text { Verification data } \\
\text { (including wave } \\
\text { and water level } \\
\text { data) }\end{array}$ & $\begin{array}{l}\text { May \& } \\
\text { November } \\
2010\end{array}$ & $\begin{array}{l}\text { Phu Quoc monitoring } \\
\text { station }\end{array}$ \\
\hline
\end{tabular}

Wave field:

Fig. 6 presents the wave distribution in the summer. Result shows that, significant wave height is around $0.6-1 \mathrm{~m}$. Wave-induced in the summer varies from 0.4 to $0.6 \mathrm{~m} / \mathrm{s}$. Long-shore current brings the sediment material from South to North (Fig. 7).

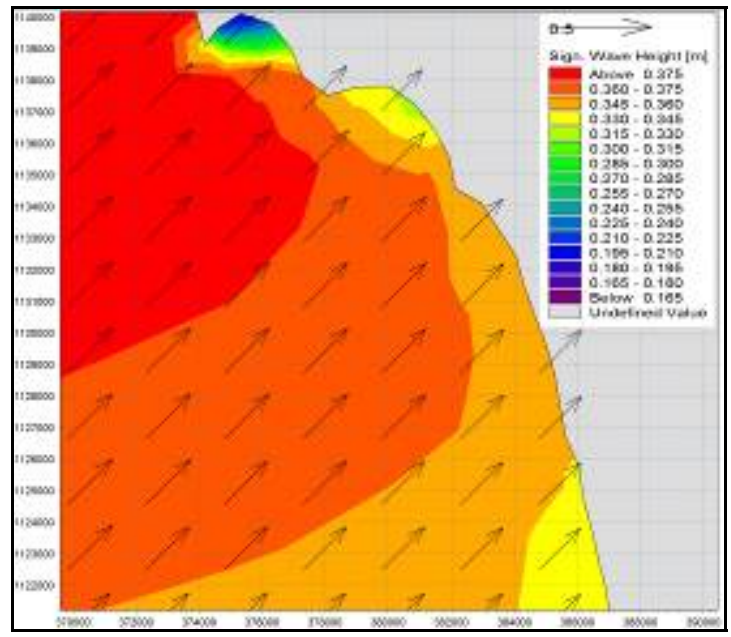

Figure 6. Wave distribution in the summer

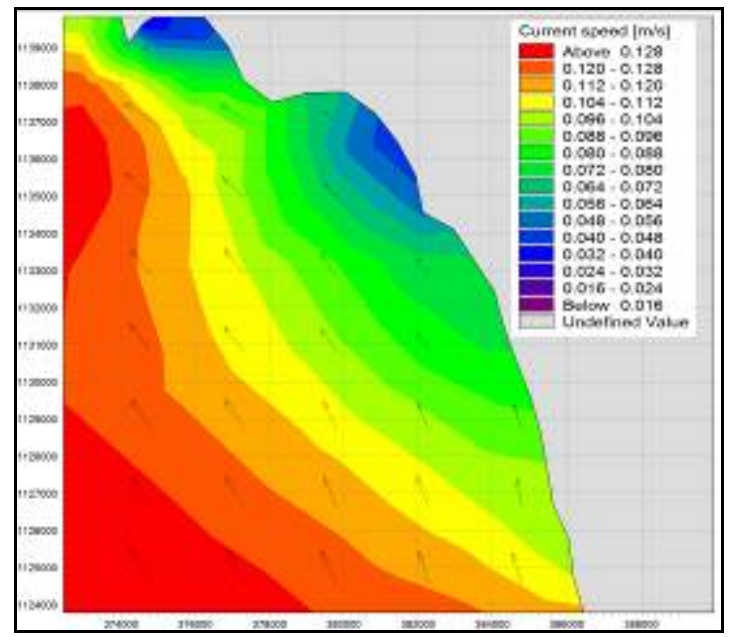

Figure 7. Current in the SW monsoon season

${ }^{1}$ Downloadable data from National Geophysical Data Center

${ }^{2}$ Wave data is extracted from Wave-watch III by NOAA

${ }^{3}$ Free data from Earth Resources Observation and Science Center 
In the winter (NE monsoon season), wave height is about $0.5 \mathrm{~m}$, current flows from North to South. Maximum current speed is about $0.5 \mathrm{~m} / \mathrm{s}$. Fig. 8 and Fig. 9 present the simulation result of wave induced and wave distribution in the NE monsoon season. In this season, beaches are replenished by sediment from the local rivers and long-shore current.

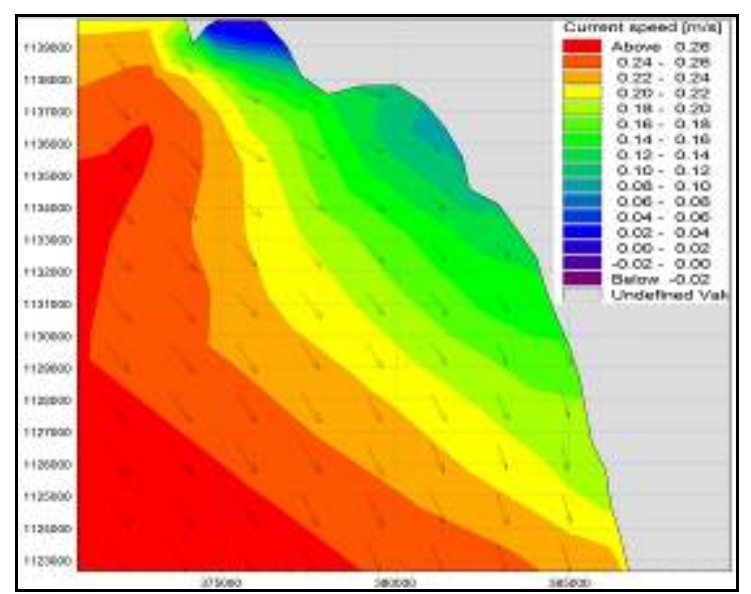

Figure 8. Current in the NE monsoon season

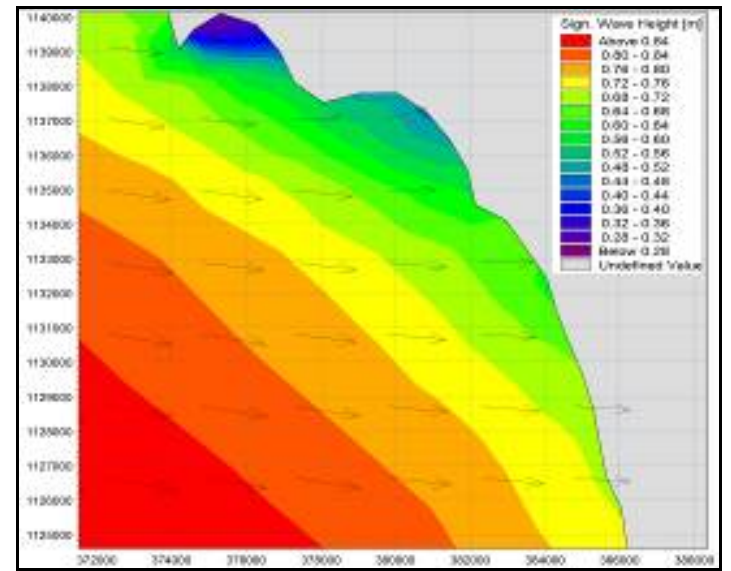

Figure 9. Wave distribution in the winter

\section{Sedimentation mechanism:}

In the SW monsoon season, high wave damages the beach structure and erodes the beach. During simulation period, rate of bed level change is $0.05 \mathrm{~m} /$ month. Fig. 10 presents the relation between wave-induced and rate of bed level change.

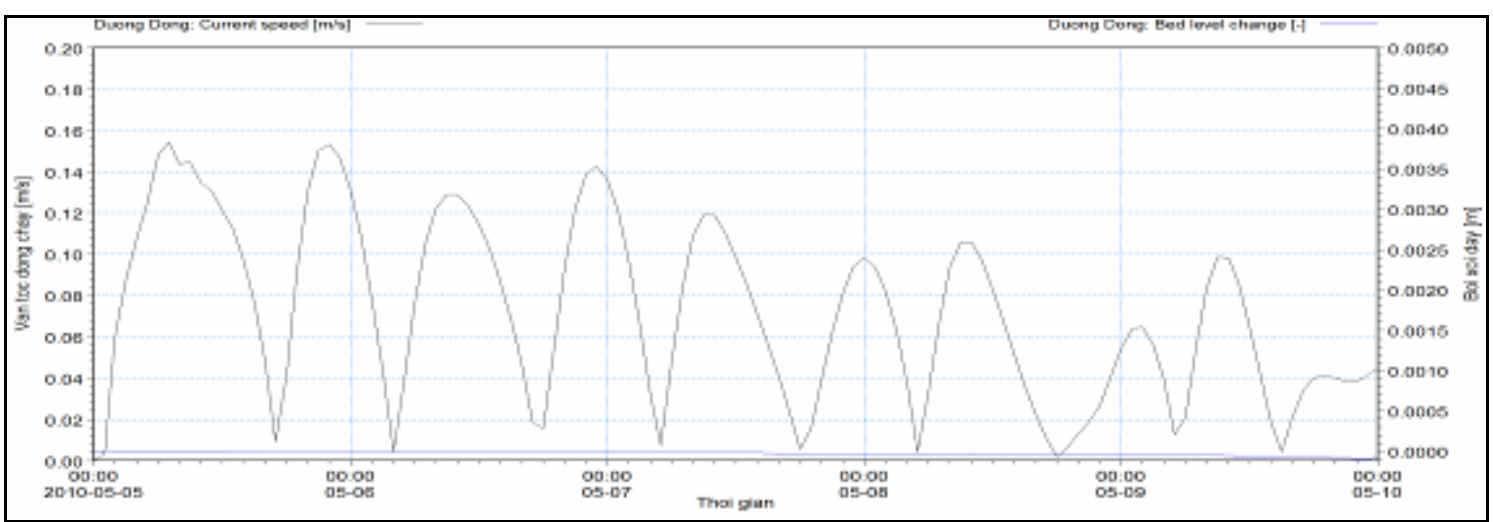

Figure 10. Relation between wav-induced and rate of bed level change in the summer

Fig. 11 presents the relation between waveinduced and rate of bed level change in the NE monsoon season. Result shows that, rate of bed level change impacted by wave induced is lower than those in the summer (SW monsoon season).

Fig. 12 presents the sedimentation rate at Duong To section. As results, maximum wave energy at the surf zone damaged the bottom structure. Results show that, at the surf zone, the wave height is maximum, damage the bottom level.

Fig. 13 simulates the shore line change under impact by wave and current within one year. Result show that, erosion occurs at the Duong Dong and Duong To beach. Besides, at the Cuu Can river estuary, beach is deposited. 


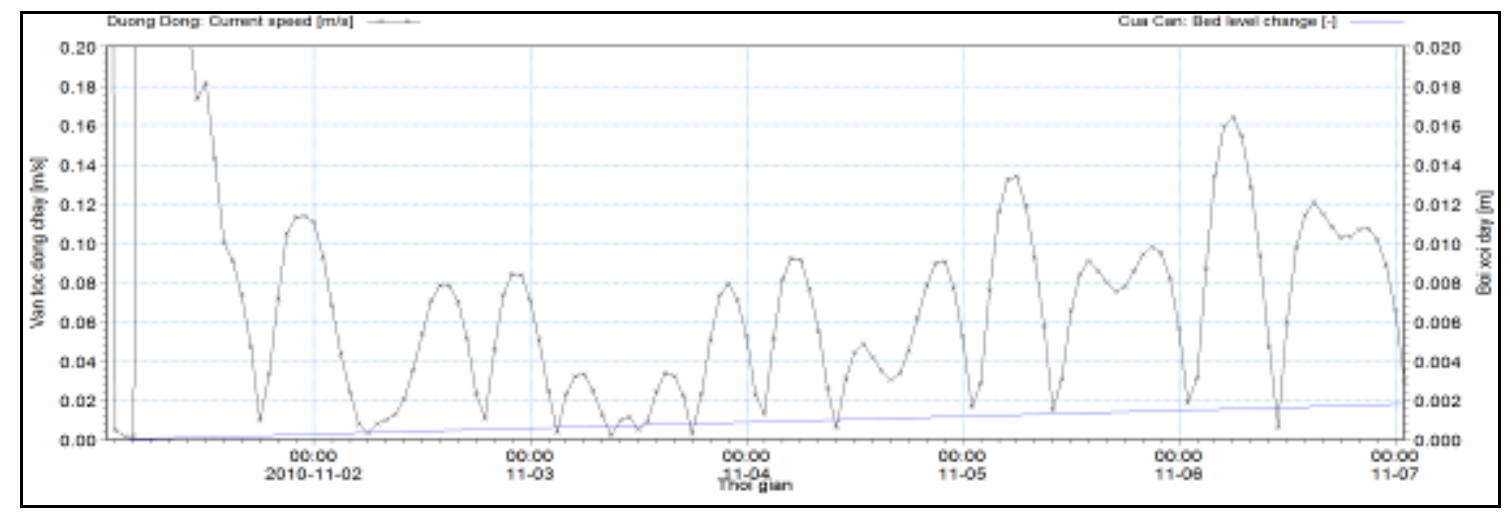

Figure 11. Relation between wav-induced and rate of bed level change in the winter

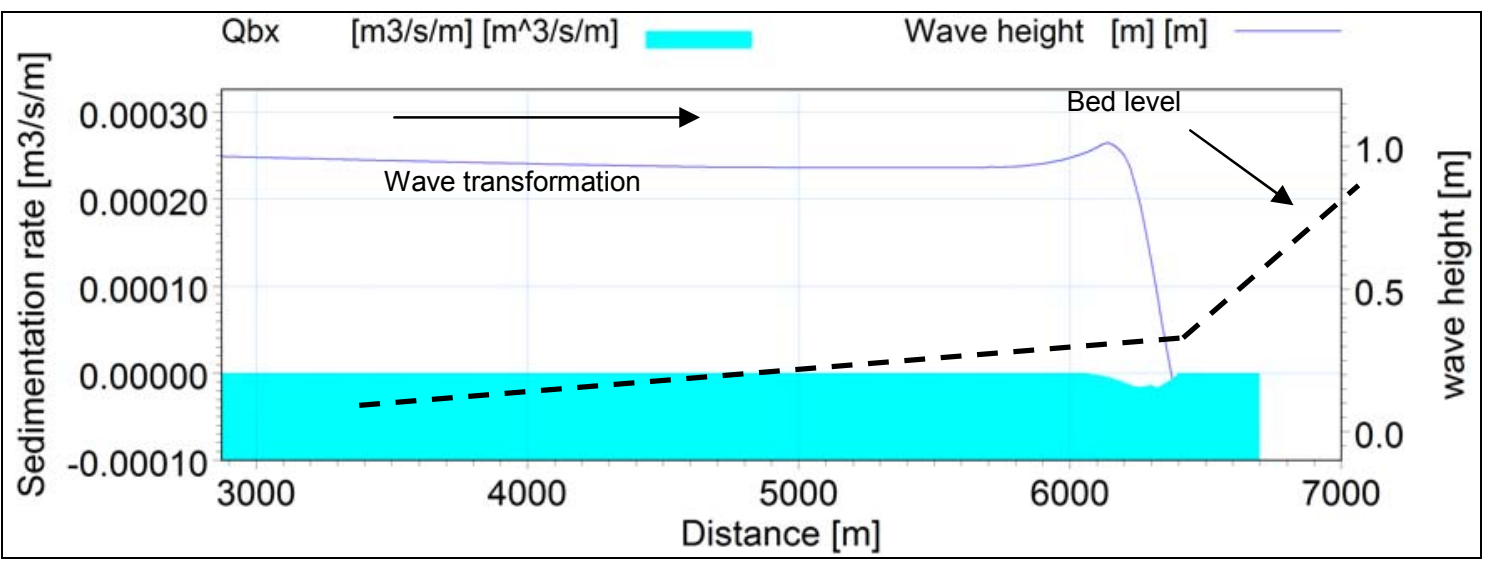

Figure 12. Sedimentation rate at Western beach

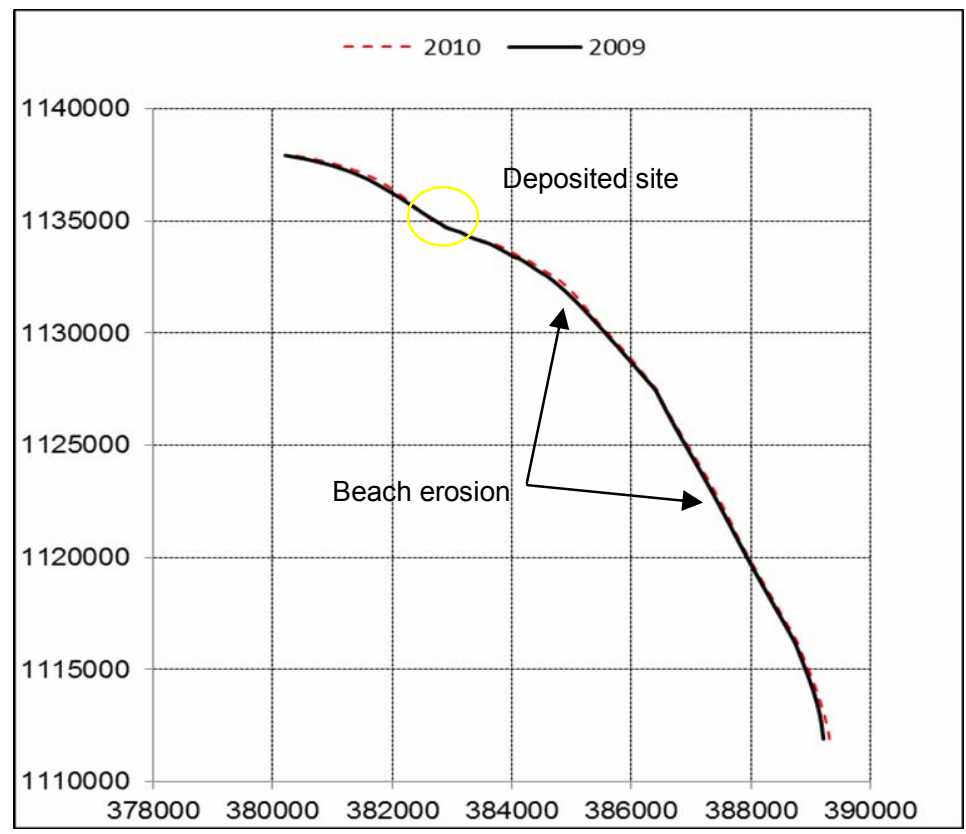

Figure 13. Shore line change simulated in 2010 


\section{Conceivable beach erosion at Western beach}

Based on field investigation and simulation results, beach erosion at western beach is mainly caused by the impact of wave affected by monsoon. In the summer, SW monsoon is

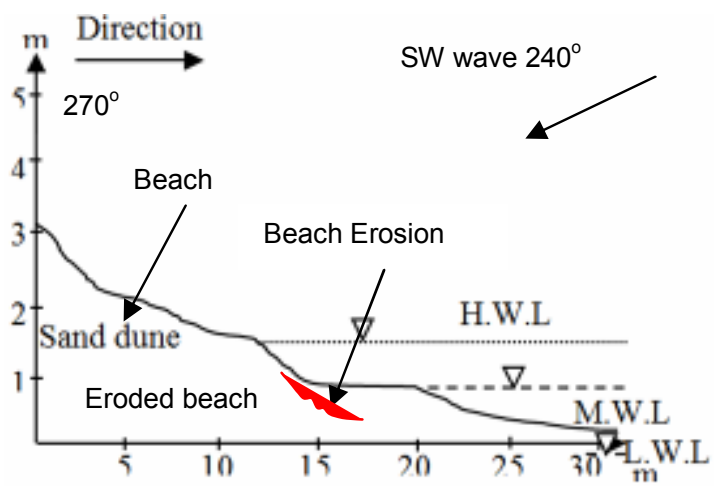

Figure 14. Beach erosion in the summer

\section{Conclusion}

Beach erosion in Phu Quoc island occurs seriously and complex. It seasonally occurs by comprehensive impacts of wave, wave induced and surge storm. Maximum rate of erosion is 3-4 $\mathrm{m}$ /year. Numerical model result has also assessed the comprehensive impact of wave, current to coastal erosion. Beach erosion affects to socioeconomic at the local area. In climate change trend, beach erosion will be more and more serious.

\section{REFERENCES}

[1] Oceanography monitoring data at Phu Quoc Station from 1979 to 2010, National Institute of Hydrology and Meteorology, Ha Noi March 2011.

[2] Duriyapong F. and Nakhapakorn K., 2011: "Coastal vulnerability assessment: a case study of dominant with high wind, generates high wave and damage the beach. Besides, in the winter, beach is deposited. Fig. 14 and Fig. 15 draw the conceivable beach erosion mechanism at Western beach in the summer and the winter $[2,4]$.

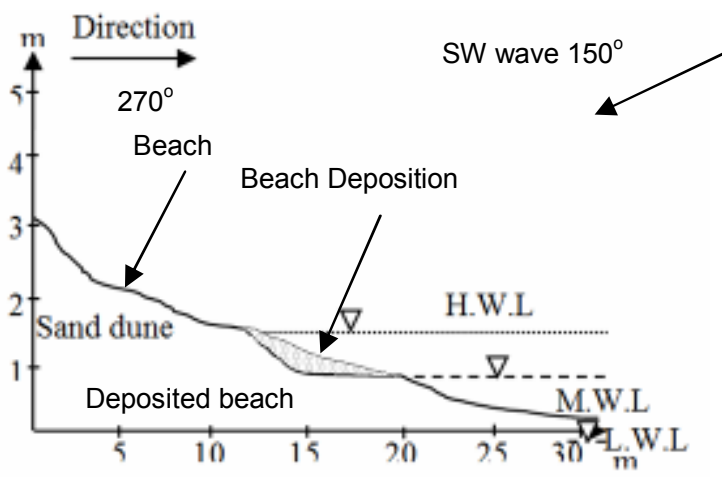

Figure 15. Beach erosion in the winter

Samut Sakhon coastal zone", Songklanakarin J. Sci. Technol. 33 (4), p469-476.

[3] Krystian W.Pilarczyk, Ryszard B.Zeidler, 1996: Offshore breakwaters and shore evolution control.

[4] Le Hoai Nam, 2013: Coastal erosion at Phu Quoc Island from 1979-2010, Doctoral dissertation, Ho Chi Minh City University of Science.

[5] Nicole Hacking, 1998: Macrofaunal community structure of beaches in northern New South Wales, Australia, Mar. Freshwater Res., 49, page 47-53.

[6] Mike 21 User Manual and Mike 21/3FM Scientific Reference Manual.

[7] http://vi.wikipedia.org/wiki/T\%E1\%BA\%A Dp_tin:Phu_quoc_1.jpg 